\title{
Pronominalkasus i subjekt med bestemmende relativsætning
}

\section{Jan Heegård Petersen, Jørgen Schack \& Eva Skafte Jensen}

\begin{abstract}
This paper reports a study of the distribution of the nominative and the oblique form in personal pronouns in Danish, specifically the distribution of the two case forms in subjects constructed as a personal pronoun with a restrictive relative clause (of the type de/ dem der kom til tiden, fik en god plads 'they/them who arrived on time, had a good seat'). The distribution is studied in written as well as spoken data. The aims are 1) to map out the actual distribution in authentic data, 2) to explain any discrepancies from the norm, be it in terms of register (spoken vs. written data) and/or grammatically.
\end{abstract}

\section{Nøgleord}

kasus, personlige pronomener, tale og skrift, dansk

\section{Indledning}

I folkeskolens afsluttende prøve i retskrivning i maj 2019 optrådte der et subjekt med et pronomen i oblik form. Den oblikke form gav anledning til adskillige henvendelser til Dansk Sprognævn og til følgende læserbrev i Berlingske:

Ved dette års afgangsprøve (8. maj) i dansk læsning og retskrivning for 9. klasse kunne man konstatere, at Undervisningsministeriet ikke behersker det danske sprog. Af ministeriets udsendte tekst til prøvens diktat finder man formuleringen: "Dem, der gerne vil have indflydelse på, hvad vi danskere vælger at se i fjernsynet, er nu gået i tænkeboks." Jeg anbefaler, at Undervisningsministeriet tager en tur med tog og bus til Bogense, hvor Dansk Sprognævn kan belære ministeriet om, hvordan man anvender personlige pronomener, så 
vi til afgangsprøver fremover undgår formuleringer som: "Dem er nu gået i tænkeboks." (Berlingske 10.5.2019, vores fremhævelser)

Læserbrevsskribenten sidestiller her et komplekst pronominalt subjekt (pronomen + bestemmende relativsætning) med et simpelt subjektspronomen, som jo i overensstemmelse med hovedreglen ville stå i nominativ (jf. afsnit 2), og ræsonnerer derfor at den oblikke form i subjektet "Dem, der gerne ..." ikke er korrekt dansk. Skribenten skriver det ikke direkte, men vil formentlig have nominativformen, dvs. de der gerne vil ..., som også er mulig $\mathrm{i}$ moderne dansk. Skribentens ræsonnementer er ikke ualmindelige, men til trods for at de umiddelbart kan virke logiske, er de ikke altid gyldige ud fra en sprogvidenskabelig betragtning. Faktisk peger læserbrevet på en kasusalternation som eksisterer i moderne dansk: Brugen af nominativ eller oblik form i subjekter der består af et personligt pronomen og en bestemmende relativsætning. I denne artikel fremlægger vi en undersøgelse af fænomenet.

Undersøgelsen er en del af et større projekt hvor vi undersøger den faktiske distribution af nominativ og oblik form i pronominalsyntagmer i såvel et skriftsprogligt som et talesprogligt korpus. Projektet udspiller sig i praksis som en række delundersøgelser hvor vi prøver at tage højde for både syntagmets indre opbygning og dets syntaktiske funktion. Desuden prøver vi at tilrettelægge undersøgelserne så det er muligt også at se isoleret på faktorer som numerus og person.

I denne artikel ser vi først på hvad udvalgte, repræsentative grammatikker og sprogbrugshåndbøger har at sige om brugen af nominativ og oblik form i subjekter der består af et personligt pronomen + en bestemmende relativsætning. Dernæst gør vi rede for kasusformernes distribution i den faktiske sprogbrug, skrift såvel som tale. I afsnit 6 inddrager vi de andre undersøgelser vi hidtil har udført, og tager stilling til på hvilken måde dette seneste bidrag påvirker de resultater vi indtil videre er nået frem til.

\section{Hvad siger grammatikkerne og sprogrigtigheds- håndbøgerne?}

Hovedreglen for distributionen af nominativ og oblik form i pronomener i moderne dansk siger at i funktion som subjekt bruges nominativ; i alle andre funktioner bruges oblik form. Der er dog i såvel den lidt ældre som den nyere grammatiske litteratur almindelig enighed om at et subjektspronomen kan have oblik form når det forbindes med en bestemmende relativsætning eller et andet bestemmende adled, altså sådan som det er tilfældet ved det 
omstridte eksempel: Dem, der gerne vil have indflydelse på, hvad vi danskere valger at se i fjernsynet, er nu gået i tankeboks (jf. Hansen 1967: 243 f.; Jacobsen \& Jørgensen 1988: 125 ff.; Becker-Christensen 2010: 207; Hansen \& Heltoft 2011: 439 f.). Subjektspronomenet kan som nævnt også stå i nominativ: De, der ..., er nu gået $i$ tenkeboks.

Den nævnte alternation mellem oblik form og nominativ ses ifølge litteraturen først og fremmest ved pronomenernes pluralisformer, vi : os, $I$ : $j e r, d e: d e m$. Ved singularisformerne gør sig til dels andre forhold gældende:

1. person singularis, $j e g: m i g$, kan normalt kun have parentetisk relativsætning:

Formen jeg betegner den talende og er dermed semantisk set fuldt afgrænset fra andre referenter. Man forventer derfor at nominativformen er altdominerende, og den er da også let at verificere: (...) Jeg, som engang lo ad min mor, fordi hun strog alting, stär nu og stryger mit sengetoj og gleder mig til at komme i seng med en god bog (Hansen \& Heltoft 2011: 441).

2. person singularis, $d u$ : dig, kan i tilfælde hvor den udpeger en person af en gruppe, have bestemmende relativsætning, og derfor kan vi her finde samme alternation som ved pluralisformerne, $\mathrm{fx}$ Dig (eller $d u$ ) der ville have vinduesplads, kom lige herop! (Hansen \& Heltoft 2011: 441).

Ved 3. person singularis, han : ham, hun : hende, er der ifølge litteraturen ikke længere nogen nævneværdig alternation mellem nominativ og oblik form når pronomenet forbindes med en bestemmende relativsætning eller et andet bestemmende adled. Her er oblik form blevet det upåfaldende kasusvalg, fx Hende der står derovre, er min kusine (Jacobsen \& Jørgensen 1988: 126). I sådanne tilfælde er nominativ (han/hun) "meget kunstlet" (Hansen 1965: 100) eller "meget unaturligt" (Hansen \& Heltoft 2011: 442).

\section{1. "Fallesledsreglen"}

I det ovenstående har vi ganske kort gjort rede for hvad der kan siges at være enighed om i repræsentative grammatikker og sprogrigtighedshåndbøger hvad angår den overordnede distribution af nominativ og oblik form i pronominale subjekter med bestemmende relativsætning: Her kan bruges såvel nominativ som oblik form; i 3. person singularis dog kun oblik form.

Hvad angår 3. person pluralis, adskiller Aage Hansen (1965) sig fra Hansen \& Heltoft (2011), idet han opererer med en regel som vedrører fællesleddets funktion i relativsætningen: 
Ved følgende relativsætning [dvs. når der følger en relativsætning efter] synes tendensen især at gå i retning af oblikform når pronomenet ikke står som subjekt for relativsætningen, medens subjektformen foretrækkes hvor pronomenet er subjekt for relativsætningen. (Hansen 1965: 102)

I 3. person pluralis bruges oblik form altså ifølge Aage Hansen især når fællesleddet (repræsenteret ved pronomenet i oversætningen) ikke er subjekt i relativsætningen, fx Dem vi skal konkurrere med rundtom $i$ verden, har forstået hvad uddannelse betyder, mens nominativ foretrækkes når fællesleddet er subjekt i relativsætningen, $\mathrm{fx} \boldsymbol{D e}$ der har fået afslag, skal nu finde på noget andet at lave. Ifølge Aage Hansen (1965) finder man også nominativ i førstnævnte slags kontekster, men den sprogbrug der beskrives hos ham, er af gode grunde af ældre dato; flere af de eksempler der skal illustrere brugen af nominativ, er over 100 år gamle. Becker-Christensen (2010) og Jacobsen \& Jørgensen (1988) opererer med en tilsvarende regel. Ifølge Becker-Christensen (2010: 208) er nominativ udelukket når fællesleddet ikke er subjekt i relativsætningen; her "kan kun akkusativformen bruges". Becker-Christensen anfører kun et eksempel i 3. person singularis, men reglen er formuleret som generel regel der gælder for personlige pronomener som sådan. Ifølge Jacobsen \& Jørgensen (1988: 126) gælder tendensen til oblik form i sådanne tilfælde især 3. person singularis. Her er tendensen "så stærk at den næsten helt sætter hovedreglen ud af spillet", og i tilfælde hvor som er udeladt, "er det kun akkusativ der kan bruges" (ibid.).

\section{Den faktiske sprogbrug}

I det følgende ser vi på om grammatikkernes og sprogrigtighedshåndbøgernes beskrivelse af kasusbrugen i pronominale subjekter med bestemmende relativsætning svarer til hvad der kan observeres i den faktiske sprogbrug. Vi har undersøgt alle 7 relevante pronomener (jeg, du, han/hun, vi, I, de) og forsøger at svare på følgende spørgsmål:

- Bruges der både nominativ og oblik form i pluralis?

- Bruges der altid oblik form i 3. person singularis?

- Spiller fællesleddets funktion i relativsætningen en rolle for kasusvalget?

- Er der forskel på kasusbrugen i skrift og tale? 
Når vi i spørgsmålene ser bort fra 1. person singularis, skyldes det at denne form nærmest aldrig forbindes med bestemmende relativsætning (jf. ovenfor). Også 2. person singularis afstår vi fra særskilt at stille spørgsmål til, da der i vores materiale er så få forekomster af den relevante konstruktionstype at der ikke kan udledes noget af dem.

\subsection{Data}

Vi har undersøgt den ovennævnte konstruktion i 2 korpusser, et skriftsprogskorpus og et talesprogskorpus. Skriftsprogskorpusset er et aviskorpus på ca. 52,5 mio. løbende ord bestående af tekster fra landsdækkende og regionale aviser fra 2017. Talesprogskorpusset består af de transskriptioner af talt dansk der udgør LANCHART-korpusset, der befinder sig ved Sprogforandringscentret, DGCSS, Københavns Universitet (Gregersen, Maegaard og Pharao 2015). Korpusset indeholdt ved undersøgelsestidspunktet (efteråret 2019) ca. 12 mio. løbende ord. Lydfilerne der ligger til grund for transskriptionerne, er optagelser af sociolingvistiske interview, dvs. løst strukturerede interview. Optagelserne stammer fra forskellige forskningsprojekter og spænder i periode fra 1970 til 2017. Talerne, både interviewere og informanter, er danskere i alderen 15-70+ år og fra flere egne af landet, om end flest fra København. Talerne er kønsmæssigt kategoriseret som 'mand' eller 'kvinde'. Dette datagrundlag er identisk med det vi har brugt i en tidligere undersøgelse (Schack, Jensen \& Petersen 2019), og det muliggør en sammenligning med den tidligere undersøgelse, se afsnit 6.1.

\subsection{Metode}

Skriftsprogsdataene er fremkommet ved søgninger på alle nominative og oblikke pronominalformer der har funktion som subjekt, og som efterfølges af en bestemmende relativsætning. I praksis brugte vi søgestrengene jeg, der ; jeg, som ; mig, der ; mig, som osv. ${ }^{1}$ Søgningerne resulterede i meget store antal forekomster, som dog indeholdt en del støj: dels eksempler med parentetiske relativsætninger, dels andre irrelevante eksempler, fx eksempler hvor som ikke fungerer som relativindleder. Samtlige eksempler blev gennemgået manuelt, og kun eksempler med bestemmende relativsætninger blev bibeholdt. For 3. person pluralis' vedkommende fremsøgte vi også eksempler uden relativindleder (typen Vi sporger de/dem han omgås), men af hensyn til sammenligneligheden med vores talesprogsdata indgår

1 Og også med både stort og lille begyndelsesbogstav: han, der/Han, der osv. 
de ikke i analyserne nedenfor, men må lægges frem ved en anden lejlighed. Konstruktioner med ekstraposition er udeladt i skriftsprogsundersøgelsen.

Talesprogsdataene er fremkommet ved søgninger på alle relevante nominative og oblikke pronominalformer. Søgeresultaterne er lagt ind i et excelark med sætningskontekster til både venstre og højre side, og med angivelse af taler og dennes alder, hjemegn, køn og socialklasse for hver forekomst. Disse søgninger og udtrækninger gav til sammen mere end 240.000 eksempler på brug af de relevante pronomener, inklusive ca. 140.000 forekomster af de i korpusset og ca. 85.000 af dem. Da LANCHARTdataene er ikke markeret for sætningsgrænser (ytringerne fortsætter ud i ét medmindre der er talerskifte), og der heller ikke bruges tegnsætning, var et større sorteringsarbejde nødvendigt for at et datasæt kunne etableres. Ved hjælp af Excels filterfunktioner blev først alle forekomster med rækkefølgen $\{$ PRONOMEN + der/som markeret som muligt relevante, og dernæst, vha. dels yderligere filtreringer, dels manuel analyse, blev alle ikkerelevante forekomster, fx sammenligningssyntagmer med som, frasorteret. Alle eksempler på ekstraposition til højre blev annoteret som sådan, fx min farfar døde for mange år siden altså ham der havde rogeriet ikke, og alle eksempler med ekstraposition til venstre, $\mathrm{fx}$ de der skal med bussen de skal møde ..., blev ligeledes annoteret som sådan (se afsnit 4.3 nedenfor). Der blev ikke fundet eksempler med parentetisk relativsætning. ${ }^{2}$

Tilbage (af de mere end 240.000 forekomster af et personligt pronomen) blev 551 sikre eksempler med den undersøgte konstruktion, inklusive eksempler med ekstraposition til venstre. Disse blev efterfølgende annoteret for pronominalt kasus, person, numerus, type af relativindleder (der eller som), forekomst i ledsætning eller hovedsætning samt pronomenets funktion i relativsætningen (subjekt, objekt, styrelse, subjektsprædikativ).

Det er en særdeles omfattende sorteringsøvelse at identificere pronomener i subjektsfunktion med relativsætninger uden eksplicit relativindleder, altså af typen fx dem du kender skal med busserne, i et så stort korpus som LANCHART uden interpunktion og markering af sætningsgrænser. En fuldstændig sortering udestår, men vi har som en foreløbig undersøgelse set på alle forekomster af de og dem hvor disse efterfølges umiddelbart af

2 Følgende forekomsttyper blev også særannoteret og derpå sorteret fra: Selvafbrydelse (fx man synes dem der kom derudefra de ha-ha-ha [dvs. latter]), gentagelse (fx ham der haltede ham der haltede han ...), ikke-grammatisk kongruens mellem subjektled i ekstraposition og på subjektplads (fx ham der taler på afdelingsmodet er det nogenlunde den samme måde at tale på) samt eksempler der ikke umiddelbart lod sig bestemme typemæssigt. 
et pronomen i nominativ, dvs. som subjekt i relativsætningen, jeg, du, han/ hun, vi, I og de.

\section{Hovedresultater}

Vi præsenterer i dette afsnit først den overordnede fordeling af nominativ og oblik form i de to datasæt. Dernæst ser vi på om den regel som vi i afsnit 4.2 kalder fallesledsreglen, følges i den faktiske sprogbrug, og i afsnit 4.3 ser vi nærmere på ekstraposition i talesprogsdataene.

\subsection{Falles resultater for tale og skrift}

Tabel 1 viser de samlede forekomster i både skrift- og taledatasættene.

Tabellen viser overordnet en klar forskel mellem tale og skrift. I talesproget foretrækkes oblik kasus, i skriftsproget nominativ. Dette indikerer to sprogbrugsnormer, men for skriftsproget, hvor datagrundlaget er større, er situationen mere kompleks.

Som det fremgår af tabel 1, er der i skriftsproget en stærk (og statistisk signifikant) tendens til nominativ i 1 . og 3. person pluralis. Tendensen er allerstærkest i 1 . person pluralis (vi). I 3. person singularis finder vi en statistisk signifikant tendens til oblik form. ${ }^{3}$ Ifølge litteraturen er nominativ i denne kontekst som nævnt meget "kunstlet" eller "unaturligt", men der er dog enkelte nominativforekomster i de sparsomme singularisdata, fx $\boldsymbol{H a n}$,

\begin{tabular}{llllll}
\hline \hline & & Skrift & & Tale & \\
& & Nominativ & Oblik & Nominativ & Oblik \\
\hline Singularis & jeg : mig & 0 & 0 & 0 & 0 \\
& du : dig & 1 & 0 & 0 & 0 \\
& han/hun : ham/hende & $3(14 \%)$ & $19(86 \%)$ & 0 & 12 \\
\hline \hline Pluralis & Total & $4(17 \%)$ & $19(83 \%)$ & 0 & 12 \\
& vi : os & $258(88,7 \%)$ & $33(11,3 \%)$ & 4 & 2 \\
& I : jer & 4 & 2 & 1 & 0 \\
& de : dem & $571(73 \%)$ & $212(27 \%)$ & $6(6 \%)$ & $89(94 \%)$ \\
\hline \hline
\end{tabular}

Tabel 1: Kasus i subjektspronomener med bestemmende relativsatning. Fordeling af nominativ og oblik $i$ singularis og pluralis $i$ skrift og tale.

$3 \mathrm{p}<0,0001$ 
der sad bagest, svingede med en hammer, mens han provede at stjele mobiltelefoner fra fodgengere (Politiken 16.7.2017, vores fremhævelse). 2. person singularis og 2. person pluralis er så sparsomt belagt at vi ikke kan konkludere noget.

For talesprogets vedkommende kan vi bedst udtale os om 3. person pluralis, hvor der er et rimeligt antal belæg; her er der en klar præference for oblik form. 3. person singularis viser også entydig præference for oblik form, men altså med kun 12 forekomster. I talesproget er både 1. og 2 . person pluralis for sparsomt belagt til at vi kan udtale os om præferencer, men det er dog bemærkelsesværdigt at for 1. person pluralis udgør nominativ 4 ud af 11 af nominativformerne, fx altså vi der vi der boede [i] kvarteret deroppe var finere (STP, København, 1987). ${ }^{4}$

\subsection{Fallesledsreglen}

Fællesledsreglen har især været nævnt i forbindelse med 3. person pluralis (de : dem), jf. afsnit 2. Datagrundlaget er for skriftsprogets vedkommende så tilpas stort i vores undersøgelse at det faktisk er muligt at afprøve denne antagelse. $^{5}$

Tabel 2 viser at sprogbrugen her klart foretrækker nominativ når fællesleddet er subjekt i relativsætningen, og oblik form når fællesleddet er objekt eller styrelse i relativsætningen. ${ }^{6}$

\begin{tabular}{lllll}
\hline Kasus & Nominativ & Oblik & Samlet \\
\hline \multirow{2}{*}{ Fællesleddet er: } & Subjekt i relativsætning & $571(73 \%)$ & $212(27 \%)$ & $783(100 \%)$ \\
& Ikke subjekt i relativsætning & $7(13 \%)$ & $49(87 \%)$ & $56(100 \%)$ \\
\hline Total & $578(69 \%)$ & $261(31 \%)$ & $839(100 \%)$ \\
\hline
\end{tabular}

Tabel 2: Kasusalternation og fallesledsreglen i skriftsproget, 3. person pluralis.

4 Der er ingen som helst indikation af at talers alder, annoteret køn, hjemegn og optagelsestidspunkt spiller en rolle for distributionen af nominativ og oblik i talesproget. Ser vi nærmere på den individuelle talers tilbøjelighed, får vi så få belæg per taler at vi ikke med rimelighed kan tale om præferencer idet hele 88 talere bidrager til de 114 eksempler. De to 'ekstremer' er: Én taler med tre eksempler med nominativ og ingen med oblik, og en anden taler med fire eksempler med oblik og ingen med nominativ. Halvdelen af de talere der indgår i datasættet, bidrager med kun ét eksempel hver.

5 Delundersøgelsen i LANCHART viste at der er 8 forekomster af dem, fx dem jeg holder af er sunde og raske (IGU, Vinderup, 2007), og ingen med de når pronomenet ikke er subjekt i relativsætningen.

$6 \mathrm{p}<0,0001$ 
Også i 1. person pluralis korresponderer langt de fleste nominativeksempler med at fællesleddet er subjekt i relativsætningen, fx (1). Dog er der (ganske få) eksempler på at oblik form bruges når fællesleddet er subjekt, fx (2).

(1) Vi, der lever $\boldsymbol{i}$ det lokale Danmark, må tage sagen $i$ egen hånd (Nordjyske Stiftstidende 23.5.2017, vores fremhævelse)

(2) Os, som selv skal betale rejsen, finder andre veje! (Århus Stiftstidende 1.11.2017, vores fremhævelse)

\subsection{Ekstraposition}

Talesprogsdataene giver mulighed for observationer af yderligere typer af kasusalternation. Vores undersøgelse inddrager som nævnt ikke ekstraposition i skriftsprog, men ikke overraskende ser vi mange tilfælde i talesprog. Dem fremlægger vi i dette afsnit. Ekstraponerede led forekommer både med nominativ og oblik kasus, fx (3) og (4). Ekstraponeret led er fremhævet med fed, subjekt med understregning.

(3) I som kommer nu I nyder bare goderne og har ingen initiativ og ingen drivkraft (HGU, København, 2006)

(4) ham der sidder oppe ved samaritervagten han er sgu ikke køn (JBR, København, 1986)

Tabel 3 viser (som tabel 1 for talesprogsdataene) at der er flere nominativforekomster i pluralis end i singularis, men generelt er der færre nominativforekomster i ekstraponerede led end i ordinære subjekter.

Sammenligner vi tallene $\mathrm{i}$ tabel 3 med tallene for talesprogsdataene $\mathrm{i}$ tabel 1, synes der at være større tendens til nominativ når syntaksen ikke indeholder ekstraposition, 11 \% vs. 4 \%. Men også kun "synes". Sam-

\begin{tabular}{lllll}
\hline & & Nominativ & Oblik & Samlet \\
\hline Singularis & jeg : mig & 0 & 0 & 0 \\
& du : dig & 0 & 0 & 0 \\
& han/hun : ham/hende & $2(2 \%)$ & $98(98 \%)$ & $100(100 \%)$ \\
\hline Pluralis & vi : os & 2 & 14 & $16(100 \%)$ \\
& I : jer & 1 & 4 & $5(100 \%)$ \\
& de : dem & $14(4 \%)$ & $302(96 \%)$ & $316(100 \%)$ \\
\hline Total & & $19(4 \%)$ & $418(96 \%)$ & $437(100 \%)$ \\
\hline \hline
\end{tabular}

Tabel 3: Talesprogets kasusalternation i led i ekstraposition. 
menholder man nominativ-oblik-alternationen i de to grupper uden og med ekstraposition, er forskellen statistisk signifikant ved en simpel khi²test, men signifikansen forsvinder når man i en mere avanceret beregning tager højde for individuelle talertendenser. Vi antager at dette afspejler den statistiske skrøbelighed ved de relativt få samlede antal forekomster af nominativ, $29 \mathrm{i}$ alt. $^{7}$

En anden observation vi har gjort i vores talesprogsdata, om end mere perifert relateret til denne artikels problemstilling, vedrører kasusalternationen i ekstraposition til højre, $\mathrm{fx}$

\section{hvad taler $\underline{I}$ så anderledes altså øh altså hvad taler $\underline{I}$ så jer der spiller fodbold sammen (XHK, Thy, 2014)}

Vores data indeholder 390 eksempler på sætninger med sådanne ekstrapositioner til højre, hvor et pronomen har en reference med subjektsfunktion i sætningskernen. Samtlige er med oblik kasus. ${ }^{8}$

\section{Opsamling}

Svarene på de spørgsmål vi stillede i afsnit 3, er som følger:

- Ja, der bruges både nominativ og oblik form i pluralis i både tale og skrift.

- Ja, der bruges næsten altid oblik form i 3. person singularis.

- Ja, fællesleddets rolle i relativsætningen spiller en væsentlig rolle for kasusvalget (for skriftsprogets vedkommende).

- Ja, der er forskel på kasusbrugen i tale og skrift.

7 Effekten af den individuelle taler er beregnet vha. en såkaldt 'mixed model-analyse', der inkluderer både 'faste faktorer' (fx tale vs. skrift eller køn) og 'random faktorer', her 'taler' (fx Levshina 2015: 192-196). Dette er i denne analyse foregået med den statistiske software $R$ (R Core Team) og værktøjspakken lme4 (Bates et al. 2015). Som for nominativ-tallene i tabel 1 er der også for eksemplerne med ekstraposition så få eksempler for den enkelte taler til at vi kan tillade os at konkludere yderligere om individuel talertendens. Hele 245 talere bidrager til de i alt 437 eksempler. De to 'ekstremer' er: En taler med 5 nominativforekomster og ingen forekomster med oblik (taleren med næstflest nominativer har 3 og 1 med oblik), og 6 talere har mellem 9 og 12 eksempler med oblik og ingen med nominativ. 173 talere bidrager med kun ét eksempel hver.

8 En undersøgelse i det samme korpus viser dog at pronomener der indgår i paratagmer, også forekommer i nominativ i ekstraposition til højre, fx er I jernaldrende du og din kone, jf. Jensen 2019a: 81. 
Vi fik altså svar på vores spørgsmål og mere til.

I tale er der klar dominans til fordel for oblik form i pluralis, både i sætninger med og uden ekstraposition; det er der også i singularis, men materialet er her så lille at man ikke kan drage konklusioner baseret herpå. Vi har ikke kunnet identificere hverken grammatiske eller sociolingvistiske faktorer der kunne forklare den alternation der er i materialet.

I skrift er der i singularis også dominans til fordel for oblik form, mens det er omvendt for pluralis. Forskellen på singularis og pluralis bemærkede Aage Hansen allerede for et halvt århundrede siden (1965: 101, 107-111).

I den udstrækning der er alternation mellem nominativ og oblik form i skriftsprogsmaterialet, ser denne ud til at være reguleret af det vi kalder fællesledsreglen, altså at formen i høj grad er afhængig af om fællesleddet er subjekt i relativsætningen eller ej.

Vores undersøgelse viser desuden at der er forskelle der har med numerus at gøre, og forskelle der har med person at gøre, og dermed at det er sværere at formulere én regel der dækker hele det morfosyntaktiske domæne end ellers antaget. Der er altså tale om et problemkompleks der både involverer faktorer som register (tale og skrift), og mere snævert lingvistiske faktorer som syntagmets indre opbygning, numerus og person (og syntaktisk funktion, se mere herom i afsnit 6.1).

\section{Perspektivering}

Som sagt udgør den fremlagte undersøgelse et delprojekt af et større projekt; i de følgende afsnit viser vi først hvordan den aktuelle undersøgelse passer ind i det større projekt. Derpå nævner vi kort hvordan vores resultater passer ind i nyere og igangværende udviklinger i kasusbrugen.

\subsection{Pronomen + bestemmende relativsatning $i$ styrelser}

I en tidligere delundersøgelse (Schack, Jensen \& Petersen 2019) har vi set på samme syntagmetype, dvs. pronomen med bestemmende relativsætning, men i en anden syntaktisk funktion, nemlig styrelse for præposition (typen til de/dem der...).

Undersøgelsen er opbygget på samme vis som den der afrapporteres i denne artikel, og omfatter altså alle 7 relevante pronomener (og samme datagrundlag, jf. afsnit 3), men det var kun i 3. person pluralis at vi fandt nogen form for afvigelse fra hovedreglen om oblik form udenfor subjekt, altså ved typen til de/dem der ... . Her fandt vi at både i tale og skrift dominerer oblik form, og at langt de fleste belæg altså lever op til hovedreglen (fordeling 
i tale: nominativ 0,6 \%, oblik form 99,4\%; fordeling i skrift: nominativ 3 $\%$, oblik form $97 \%$ ). Nærværende undersøgelse giver et mindre entydigt billede, og faktorer som person og numerus bidrager tilsyneladende til at det samlede billedes kompleksitet.

\subsubsection{Fellesledsreglen}

I afsnit 4 (tabel 2) viste vi at fællesleddets funktion i relativsætningen spiller en rolle for kasusvalget: Der er en signifikant tendens til at vælge oblik form når fællesleddet ikke er subjekt i relativsætningen. Når fællesleddet er subjekt, er der en signifikant tendens til nominativ, men oblik form bruges dog i over en fjerdedel af tilfældene. ${ }^{9}$ Noget tilsvarende, om end endnu tydeligere, gør sig gældende i den omtalte tidligere undersøgelse hvor denne syntagmetype er styrelse for en præposition (Schack, Jensen \& Petersen 2019). I tabel 4 vises tallene herfor. Som det fremgår, er der kun én forekomst hvor fællesleddet ikke er subjekt i relativsætningen. ${ }^{10}$

Det har været foreslået at de i den aktuelle syntagmetype i funktioner udenfor subjekt, ikke skal analyseres som pronomen, men som artikel (se fx Heltoft 1991: 131-135, 1992: 87-91; Hansen \& Heltoft 2011: 443), hvorved spørgsmålet om eventuel kasus bliver irrelevant (jf. også Schack, Jensen \& Petersen 2019: 449 f.). Vores undersøgelse peger på at alternationen de : dem faktisk kan forklares som en kasusalternation, idet formen de kun eller næsten kun indtræder i tilfælde hvor fællesleddet er subjekt i relativsætningen. Denne analyse er ikke ny (jf. Hansen 1965: 102, se afsnit 2.1).

\begin{tabular}{llll}
\hline \hline Skrift de/dem & Nominativ & Oblik & Samlet \\
\hline Subjekt i relativsætning & $135(99,2 \%)$ & $3373(88,4 \%)$ & $3508(88,8 \%)$ \\
Ikke subjekt i relativsætning & $1(0,8 \%)$ & $407(11,6 \%)$ & $408(11,2 \%)$ \\
\hline Total & $136(100 \%)$ & $3780(100 \%)$ & $3916(100 \%)$ \\
\hline \hline
\end{tabular}

Tabel 4: Kasusalternation og fallesledsreglen for pronominalformer styret af en preposition (skriftsprog; Schack, Jensen \& Petersen 2019).

$9 \mathrm{p}<0,001$

10 Eksemplet er: Kunderne i OneLounge kan valge enten en flex-ordning, hoor de betaler for de, som de bruger. Der er muligvis tale om en slåfejl (de for det), hvilket vil diskvalificere det som eksempel på den i denne artikel undersøgte konstruktion (jf. Schack, Jensen \& Petersen 2019: 452). I givet fald er samtlige forekomster i data (jf. tabel 4) sætninger hvor fællesleddet i form af et pronomen er subjekt i relativsætningen. 
Jørgensen (2000) efterprøver også denne analyse, men kommer frem til mindre tydelige resultater for dansks vedkommende (jf. også Schack, Jensen \& Petersen 2019: 450 f.). Til gengæld peger han på at man både i nogle svenske og nogle norske dialekter har hvad man kunne kalde 'styring fra relativsætningen', altså at fællesleddets funktion i relativsætningen kan regulere kasusformen i æællesledspronomenet (Jørgensen 2000: 195 f., 241, 255). En sådan tankegang passer godt til analysen af vores data.

\subsection{Pronominalkasus $\boldsymbol{i}$ komplekst opbyggede syntagmer}

Hvad angår syntagmetypen pronomen + bestemmende relativsætning, ser vi altså at nogle tendenser er ens, især tendensen i skriftsproget til nominativ hvor fællesleddet er subjekt i relativsætningen, dvs. tendensen til at følge fællesledsreglen. Vi ser også at de pågældende tendenser er tydeligere når syntagmet er styrelse for en præposition end når det fungerer som subjekt. Der er altså netop tale om tendenser og ikke en fast regel efter hvilken pronominale kasus retter sig. Hvad angår distinktionen tale : skrift, se afsnit 6.6.

For moderne dansks vedkommende er det velkendt at hovedreglen om nominativ i subjekt og oblik form i alle andre funktioner, udfordres når subjektet er opbygget som et komplekst syntagme (Diderichsen 1946: 109-110; Hansen 1965: 102-103; Hansen 1967: 242-245; Hansen 1972; Jørgensen 2000: 168-194; Jacobsen \& Jørgensen 1988: 122-128; Hansen \& Heltoft 2011: 436-443; Schack 2013; Schack, Jensen \& Petersen 2019; Jensen 2018, 2019b). I praksis kommer dette til udtryk ved at en del komplekst opbyggede subjekter ikke står i nominativ, og at man derfor kan finde alternation mellem nominativ og oblik form ved de fleste typer komplekst opbyggede subjekter. Dette understøttes af vores undersøgelse.

Det understøttes også af en anden delundersøgelse i vores problemkompleks, nemlig distributionen af de to kasusformer i syntagmer opbygget som paratagmer (jf. Jensen 2018, 2019b). I denne undersøgelse har det også vist sig at det særligt er ved subjektsfunktionen man finder alternation mellem nominativ og oblik form (jf. Gitte og jeg/mig så en snog). Desuden viste det sig at der var en markant forskel på dette i tale og skrift, jf. tabel 5: 


\begin{tabular}{lllllll}
\hline \hline & Skrift & & & Tale \\
& Nominativ & Oblik & & Nominativ & Oblik & \\
\hline jeg : mig & 4.778 & 13 & 4.791 & 195 & 153 & 348 \\
& $(99,7 \%)$ & $(0,3 \%)$ & $(100 \%)$ & $(56,0 \%)$ & $(44,0 \%)$ & $(100 \%)$ \\
du : dig & 38 & 13 & 51 & 51 & 32 & 83 \\
& $(74,5 \%)$ & $(25,5 \%)$ & $(100 \%)$ & $(61,4 \%)$ & $(38,6 \%)$ & $(100 \%)$ \\
han : ham & 2.534 & 7 & 2.541 & 23 & 27 & 50 \\
& $(99,7 \%)$ & $(0,3 \%)$ & $(100 \%)$ & $(46,0 \%)$ & $(54,0 \%)$ & $(100 \%)$ \\
hun : hende & 1.883 & 17 & 1.900 & 9 & 21 & 30 \\
& $(99,1 \%)$ & $(0,9 \%)$ & $(100 \%)$ & $(30,0 \%)$ & $(70,0 \%)$ & $(100 \%)$ \\
\hline \hline Total & 9.233 & 50 & 9.283 & 278 & 233 & 511 \\
& $(99,5 \%)$ & $(0,5 \%)$ & $(100 \%)$ & $(54,4 \%)$ & $(45,6 \%)$ & $(100 \%)$ \\
\hline \hline
\end{tabular}

Tabel 5: Fordelingen af nominativ og oblik form i pronomener der indgår i paratagmer der fungerer som subjekt.

\subsection{1. og 2. person pluralis}

Eksisterende beskrivelser af kasus i komplekse syntagmer kommer ikke meget ind på 1.og 2. person pluralis; forholdene beskrives som uklare (Jensen 2019b: 99). Dels mangler der empiri, dels giver den empiri der findes, ikke entydige resultater. Også vores empiriske grundlag er spinkelt og nogle steder ligefrem hullet; men hvor der faktisk er et solidt datagrundlag ( $v i$ : os i skriftsprog, jf. afsnit 4), peger resultaterne i samme retning som ved 3. person pluralis. Vores undersøgelse bidrager altså til at udfylde nogle af hullerne i forskningen.

\subsection{Ekstraposition}

Vores undersøgelse af talesprogsmaterialet viser at der er mange flere eksempler med pronomen med relativsætning i ekstraposition til venstre end ved ordinære subjekter i sætningskernen. Dette er kompatibelt med fremstillingerne i Hansen \& Heltoft (2011: 1830 ff.) og Brøcker m.fl. (2012), som begge fremhæver ekstraposition som almindelig i talesprog. Litteraturen om ekstraposition nævner dog ikke eksplicit hvordan det forholder sig med kasusbrugen ved pronomener i ekstraposition pronomener, men følger vi Jensen (2019a: 79), som foretager en syntese af eksisterende beskrivelser, kan vi se "at forventningen her er at sådanne vil stå i oblik form". Den forventning kan vi bekræfte idet hele $96 \%$ af pronomenerne i ekstraposition til venstre er i oblik form, og alle pronomener i ekstraposition til højre har oblik form. 


\subsection{Sprogudvikling}

Traditionelt bruges nominativ ved pronomener der fungerer som subjekt. Brugen af oblik form i komplekst opbyggede subjektssyntagmer kan dokumenteres fra slutningen af 1800-tallet (Jensen, under bedømmelse). Muligheden for at bruge oblik form i denne type syntagmer rammer ikke kun pronomener med bestemmende relativsætning, men også subjektsparatagmer som dem vist i tabel 5, og subjektspronomener ledsaget af et bestemmende adverbial (jf. ham på tredje er en flink fyr) og bestemmende nominal (fx hende den dygtige kan hjalpe os). Derved opstår der i sprogsamfundet konkurrerende regler, en der holder fast i traditionen, og en der slipper denne til fordel for den moderne måde at gøre tingene på. I visse tilfælde ser man at den nye regel fuldstændig udkonkurrerer den gamle; det er fx tilfældet i typen med bestemmende adverbial; her kan man ikke mere bruge nominativ (se også Hansen 1965: 100; Jensen, under bedømmelse). I subjektspronomener med bestemmende relativsætning kan man dog stadig finde begge regler i brug.

\subsection{Skrift versus tale}

Både denne og vores forrige undersøgelse (Schack, Jensen \& Petersen 2019) har vist klare forskelle mellem tale og skrift; det samme gælder undersøgelsen af pronomener i paratagmer, jf. tabel 5: Nominativ er langt mere fremtrædende i skrift, i tale er nominativ sjælden. I den forbindelse kan vi dog ikke lukke øjnene for at det skriftsprog vi har undersøgt, har været underlagt korrekturlæsning, og at en oblik form i forbindelse med denne kan være blevet ændret til nominativ. Oblik form kan tænkes at være mere udbredt end vi kan se af avismaterialet, og vi kan således have en ususbaseret norm a la talesproget og en konkurrerende præskriptiv norm som kommer til udtryk i korrekturlæst skriftsprog. Fremtidige undersøgelser af mere spontant skriftsprog og af mere formelt talesprog vil kunne kvalificere en sådan antagelse.

Vores undersøgelser peger ikke desto mindre på en registerforskel, hvor skriftregistret i højere grad realiserer hvad Hansen \& Heltoft (201 1: 442) kalder "ældre norm". Eller, med andre ord, vores undersøgelser peger på som andre før vores - at sprogudviklingen er længere fremme i talesproget end i det (mere formelle) skriftsprog, som den kommer til udtryk i aviser, i hvert fald hvad angår kasus i subjektsfunktion. 


\subsection{Et komplekst problemkompleks}

Som tidligere nævnt indgår denne undersøgelse i en større undersøgelse af pronominalkasus i dansk. Som i tidligere undersøgelser finder vi i denne aktuelle undersøgelse at der er mange faktorer der spiller ind på valget af nominativ og oblik form i komplekst opbyggede syntagmer, herunder som mindstemål tale og skrift, syntaktisk funktion, person og numerus.

Det er ikke ualmindeligt at formulere en alternativ regel til hovedreglen. Nogle af de mest kendte forslag er 1) 'trykfordelingsreglen', efter hvilken obligatorisk trykstærke pronomener står i oblik form (fx Hansen 1972; Brink \& Lund 1975), 2) 'oblik form som default'-reglen, efter hvilken oblik form altid kan bruges bortset fra de tilfælde hvor et pronomen uden ledsagende led fungerer som subjekt (fx Heltoft 1997: 233; se også Schack 2013: 67, 68), og 3) - som er beslægtet med 2) - 'anaforireglen', efter hvilken hovedreglen kun gælder ved såkaldt anaforiske led - det vil i praksis sige pronomener uden ledsagende led i entydig syntaktisk funktion - (Hansen \& Heltoft 2011 : 438 f.), se også en mere udførlig redegørelse i Schack (2013).

Vores aktuelle undersøgelse og de øvrige undersøgelser vi indtil videre har foretaget, viser at det er svært at opstille en hovedregel og én alternativ regel der tager højde for alle de nævnte faktorer (tale/skrift, syntagmets indre opbygning, person, numerus). Hvis man vil have ordentlig indsigt $\mathrm{i}$ hvad der regulerer distributionen af nominativ og oblik form, er man altså nødt til at gøre som vi gør: brække problemkomplekset i mindre stykker for derpå at sætte delene sammen igen. Det projekt er vi er i gang med, og med tiden leder det frem til at vise om der kan formuleres en overordnet regel for kasusdistributionen i moderne dansk.

\section{Om forfatterne}

Jan Heegård Petersen, ph.d., lektor ved Københavns Universitet. Jørgen Schack, cand.mag., seniorforsker ved Dansk Sprognævn. Eva Skafte Jensen, dr.phil., seniorforsker ved Dansk Sprognævn.

\section{Litteratur}

Bates, D., M. Martin, B. Bolker \& S. Walker (2015): Fitting Linear MixedEffects Models Using \{lme4\}. Fournal of Statistical Software 67(1), 1-48. doi: $10.18637 /$ jss.v067.i01.

Becker-Christensen, C. (2010): Dansk syntaks. Indforing i dansk satningsgrammatik og setningsanalyse. København: Samfundslitteratur. 
Brink, L. \& J. Lund (1975): Dansk rigsmål, lydudviklingen siden 1840 med sarligt henblik på sociolekterne $i$ Kobenhavn. København: Gyldendal.

Brøcker, K.K., M.G.T. Hamann, M. Jørgensen, S.B. Lange, N.H. Mikkelsen \& J. Steensig (2012): Samtalesprogets grammatik - fire fænomener og nogle metodiske overvejelser. NyS - Nydanske Sprogtudier 42, 10-40.

Diderichsen, P. (1946): Elementer Dansk Grammatik. 3. udg. København: Gyldendal 1987.

Gregersen, F., M. Maegaard \& N. Pharao (2015): The LANCHART Corpus. I: The Oxford Handbook of Corpus Phonology. J. Durand, U. Gut \& G. Kristoffersen (red.). Oxford: Oxford University Press, 534-545.

Hansen, Aa. (1965): Vort Vanskelige Sprog. 2. reviderede og udvidede udgave. København, Grafisk Forlag.

Hansen, Aa. (1967): Moderne Dansk. Bind 2. København, Det Danske Sprogog Litteraturselskab. Grafisk Forlag.

Hansen, E. (1972): Dr. Jekyll og Mr. Hyde i Dansk Grammatik. En filologisk skitse. I: Gleden ved grammatik. Udvalgte artikler og afhandlinger. H. G. Jacobsen \& H. Jørgensen (red.). København: Hans Reitzels Forlag 2001, 98-1 10.

Hansen, E. \& L. Heltoft (201 1): Grammatik over Det Danske Sprog. København: Det Danske Sprog- og Litteraturselskab.

Heltoft, L. (1991): Talesprogets tale. I: Møde om Udforskningen af Dansk Sprog 3. M. Kunøe \& E.V. Larsen (red.). Århus, 126-143.

Heltoft, L. (1992): Topologiens plads i en sprogteori. Sprogvidenskabelige arbejdspapirer fra Kobenhavns Universitet 2, 67-98.

Heltoft, L. (1997): Hvem opslugte hvo. Et bidrag til beskrivelsen af det danske kasussystems udvikling. I: Ord, Sprog oc artige Dict. Festskrift til Poul Lindegård Hjorth. F. Lundgreen-Nielsen, M.A. Nielsen \& J. K. Sørensen (red.). København: Universitets-Jubilæets danske Samfund \& C. A. Reitzel, 227-256.

Jacobsen, H. G. \& P. S. Jørgensen (1988): Håndbog i Nudansk. 6. udg. København: Politikens Forlag 2013.

Jensen, E.S. (2018): Norm, usus og korpus. Kasusvalg i paratagmer. I: Dansk til det 21. Arhundrede - sprog og samfund. T.K. Christensen, C. Fogtmann, T.J.Jensen, M.S. Karrebæk, M. Maegaard, N. Pharao \& P. Quist (red.). København: U Press, 171-182.

Jensen, E.S. (2019a): "Peter og mig, vi gik i biografen". Paratagmer og kasus i ekstraposition. I Ny forskning i grammatik. Fallespublikation 26. M. Birkelund, H. Jørgensen \& S. Vikner (red.). København: Dansk Sprognævn, 71-88. doi: 10.7146/nfg.v0i26.115994. 
Jensen, E.S. (2019b): “Gitte og mig" - kasus i paratagmer i moderne dansk talesprog. Danske talesprog 19, 77-107.

Jensen, E.S. (under bedømmelse): Et system i stadig bevægelse. Pronominalkasus i dansk. Indsendt til Danske Studier.

Jørgensen, H. (2000): Studien zur Morphologie und Syntax der festlandskandinavischen Personalpronomina - mit besonderer Berücksichtigung des Dänischen. Aarhus: Aarhus University Press.

Levshina, N. (2015): How to do linguistics with R. Data exploration and statistical analysis. Amsterdam: John Benjamins.

R Core team (2019): A Language and Environment for Statistical Computing. $R$ Foundation for Statistical Computing. Østrig: Wien. https://www.R-project.org.

Schack, J. (2013): Dig og mig og vi to. Synspunkter på kasus i moderne dansk. NyS - Nydanske Sprogstudier 45, 48-72.

Schack, J., E.S. Jensen \& J.H. Petersen (2019): “Tak til alle de der gør en indsats for vores sikkerhed". Bagom dronningens kasusvalg. I: Møde om Udforskningen af Dansk Sprog 17. Y. Goldshtein, I. Schoonderbeek \& T.T. Hougaard (red.). Århus, 443-456. 